\title{
GROWING ONTARIO RESPONSIBLY: A LOOK AT THE IMPACT OF THE GROWTH PLAN FOR THE GREATER GOLDEN HORSESHOE ON ONTARIO'S ECONOMIC ENVIRONMENT
}

\author{
by \\ Kelly O'Hanlon \\ (Bachelor of Commerce, specialization in management, Rotman Commerce, University of Toronto, \\ 2014) \\ A Major Research Paper \\ presented to Ryerson University \\ in partial fulfillment of the requirements for the degree of \\ Master of Planning \\ in \\ Urban Development \\ Toronto, Ontario, Canada, 2017 \\ (C) Kelly O'Hanlon 2017
}




\section{Author's Declaration for Electronic Submission of a MRP}

I hereby declare that I am the sole author of this MRP. This is a true copy of the MRP, including any required final revisions.

I authorize Ryerson University to lend this MRP to other institutions or individuals for the purpose of scholarly research.

I further authorize Ryerson University to reproduce this MRP by photocopying or by other means, in total or in part, at the request of other institutions or individuals for the purpose of scholarly research.

I understand that my MRP may be made electronically available to the public. 


\section{ABSTRACT}

GROWING ONTARIO RESPONSIBLY: A LOOK AT THE IMPACT OF THE GROWTH PLAN FOR THE GREATER GOLDEN HORSESHOE ON ONTARIO'S ECONOMIC ENVIRONMENT

AUTHOR: Kelly O'Hanlon (Bachelor of Commerce, specialization in management, Rotman Commerce, University of Toronto, 2014), Candidate for the degree of Master of Planning in Urban Development at Ryerson University (2017)

This Major Research Paper (MRP) will examine the consequences of the proposed Growth Plan for the Greater Golden Horseshoe (GGH) on the economic trends of southern Ontario. As a type of regulatory tool, the Growth Plan has inevitable market impacts that must be studied, understood, and mitigated when making policy decisions. Increasing evidence has pointed towards housing affordability, and supply of land and housing types, as two broad market impacts of regulatory tools that fall under the branch of 'growth management', 'urban containment', and 'smart growth'. The subject of this MRP is the economic impact of the Growth Plan for the Greater Golden Horseshoe, imposed by the provincial government, and implemented on a municipal level. In 2015, the province initiated its first ten-year review of the 2006 Growth Plan for the GGH. The province released proposed amendments to the Growth Plan in the summer of 2016 following an analysis by a selected panel of experts and input from community consultations. It is anticipated that these proposed amendments will exasperate the widespread affordability issues of the GGH, create a more homogenous built form and building typology, and ignore the diversity of municipalities across the impacted area. A thorough analysis of these adverse effects will be provided along with recommendations on how the province can better balance the environmental, social, and economic goals of the Greater Golden Horseshoe.

KEY WORDS: Growth Plan; land use regulation; housing affordability; land supply; Greater Golden Horseshoe; Greater Toronto Area 


\section{TABLE OF CONTENTS}

Author's Declaration

Abstract

Table of Contents $\quad$ iv

List of Figures $\quad \mathrm{V}$

1.0 Introduction 1

2.0 Format of this Major Research Paper 2

3.0 Ontario's Current Economic Situation 3

3.1 Introduction 3

3.2 Summary of the GTA Housing Market 2016 Performance 4

3.2.1 Inventory 4

3.2.2 Sales 5

3.2.3 Price 6

$\begin{array}{ll}\text { 3.3 Forecast for the GTA Housing Market } & 7\end{array}$

4.0 Review of the Growth Plan for the Greater Golden Horseshoe 10

$\begin{array}{ll}4.1 \text { Introduction } & 10\end{array}$

4.2 Intention of this Review 10

4.3 Evidence of the Economic Impact of the Growth Plan 11

4.4 Economic Consequence \#1 - Land Supply and Housing Affordability 13

4.4.1 Supply of Serviced Land 13

4.4.2 Static Built Boundary 14

4.5 Economic Consequence \#2 - Lack of Housing Choice 16

4.6 Economic Consequence \#3 - Is a 'One-Size Fits All’ Approach 20

Appropriate?

$\begin{array}{ll}\text { 5.0 Recommendations } & 24\end{array}$

$\begin{array}{ll}6.0 \text { Next Steps } & 25\end{array}$

$\begin{array}{ll}7.0 \text { Works Cited } & 26\end{array}$ 


\section{LIST OF FIGURES}

Figure 1: Year of 2016 GTA Housing Performance Snapshot 4

Figure 2: Monthly Remaining New Home Inventory by Type 4

Figure 3: Annual New Home Sales $\quad 5$

Figure 4: Monthly New Home Price Index 6

Figure 5: Average Prices of Available Inventory (2016) 6

Figure 6: 2017 GTA Housing Forecast $\quad 7$

Figure 7: GTA Average Home Prices $\quad 8$

Figure 8: The Effect of Achieving 80 People + Jobs/hectare 15

Figure 9: Increase in Average Sale Prices of New and Resale in Ground-Related Housing in the GTA, 17 $2005-2015$

Figure 10: Ground-Related Housing Starts by Unit Type, GTA, 2001 - 2014

Figure 11: What does 80 People + Jobs/hectare look like? 18

Figure 12: Preferred Housing Type of Prospective Buyers, GTA, November 2015

Figure 13: Intensification...One Size Doesn't Fit All 20 


\subsection{INTRODUCTION}

In 2015, the province initiated a coordinated review of all long-term land use planning documents including Ontario's Greenbelt Act (2005), Niagara Escarpment Plan (2005), the Oak Ridges Moraine Conservation Plan (2002), and the Growth Plan for the Greater Golden Horseshoe (2006). As a result of the review, eighty-seven recommendations were compiled into a report released by an appointed advisory panel following the input of various stakeholders, on changes that should be considered for Ontario's land use regulations. Later, in the summer of 2016, proposed amendments to the documents were released by the province. Comments on the proposal from interested parties were submitted on October 31, 2016. It is expected that updated plans will be released in early 2017 from the province.

This Major Research Paper (MRP) will take a look at the impact of the proposed amendments on the Growth Plan for the Greater Golden Horseshoe (GGH). It is anticipated that there have been a collection of negative consequences on the economic and social environment of southern Ontario. As such, it is imperative to consider changes to the policy during this ten-year review that will better balance the economic, social, and environmental constructs of southern Ontario as it continues to experience exponential growth and change.

There is no doubt that the Growth Plan serves an important role in the smart growth of Ontario. According to the proposed Growth Plan, by the year 2041, the population for the GGH is expected to increase to $13,480,000$ people with the majority of this population expected to concentrate in the Region of York, the Region of Peel and the City of Toronto (MMAH, Proposed Growth Plan, 93). In anticipation of this growth, the plan serves the purpose of controlling and organizing jobs, land use, and growth. With the ten year review period now underway, it is important to look not only at what the plan has done well, but also to consider the negative impacts.

What is often neglected is the economic impact that this legislation has had. Basic economic theory says that when supply is restricted, prices increase. Land is a commodity that is subject to market conditions. Ontario is facing an affordable housing crisis and is experiencing rising home prices, especially in the market for groundrelated housing. With the inception of the Greenbelt and the density and intensification requirements of the Growth Plan, the supply of land and the supply of ground-related housing has been restricted. Many people argue that there is not enough evidence to prove that the Growth Plan and the Greenbelt are a cause for these trends, but this MRP will show evidence that there is in fact reasonable concern that is being neglected by the province and decision makers. There are tools that can be implemented to help mitigate the effects, but consideration of these tools have been absent from the proposed changes to the Plan. Instead, the proposed Growth Plan will exasperate these effects by increasing intensification and density requirements in a uniform pattern across the region. 


\subsection{FORMAT OF THE PAPER}

In order to investigate the impact of the Growth Plan on the economic trends of the GGH, this MRP will begin by examining the trends and forecast for the housing market in the Greater Golden Horseshoe. By understanding, the economic impact, the consequences of the Growth Plan can be better understood. Next, the MRP will look at specific economic consequences that have had an impact on the Greater Golden Horseshoe as a result from the policy implemented to control growth within the region. The three economic consequences that will be highlighted include:

- $\quad$ Land Supply and Housing Affordability: As a type of land control and regulation tool, the Growth Plan restricts the supply of serviced land for development purposes. As a result of the restricted supply, it is argued that housing prices for ground-related homes have increased, adding to the affordability crisis in Ontario's housing market. "The 52\% decline in GTA unsold ground-oriented new home supply contributed to the $19.9 \%$ yearover-year increase in that market segment" (Myers 5).

- Lack of Housing Choice: The Growth Plan includes densification and intensification targets that promote more compact and dense communities. With the proposed increases in these targets, the supply of groundrelated, especially single-detached and semi-detached homes, will continue to be extremely low. This is having adverse effects, as the Canada Mortgage and Housing Corporation (CMHC) reports "increasing singlefamily home prices in the GTA are motivating buyers to purchase more affordable homes in nearby CMAs, driving up prices in those centres" and restricting some first-time buyers from entering the ownership market, despite strong demand from this cohort in the near term (CMHC, "Housing Market Insight", 1). "Most polls show Canadians prefer ground-oriented housing to high-rise living, even when you change the question and introduce a financial and locational component" (Myers 5).

- "One-size fits all" approach to intensification and density targets: Intensification and density targets are generally applied across the entire GGH. Due to numerous factors including the diversity of built form and demographic make-up, standard targets are not appropriate for the growth of the GGH.

After discussing these economic consequences at length, the paper will briefly discuss the next steps in the review process as it is ongoing. 


\subsection{ONTARIO'S CURRENT ECONOMIC SITUATION}

\subsection{INTRODUCTION}

Before examining the impact that the Growth Plan has had on the housing market in Ontario, it is important to first look at how that market has performed in the past and the forecast for how it is expected to change. This section will examine the trends and performance indicators in the market, how it performed from 2006 to 2016, focusing on output in 2016, and forecasts for the future. The housing market in Canada has been a strong economic performer over the past decade varying greatly by region. Toronto and Vancouver are the two largest markets in Canada, and have been on a housing boom that has lasted more than a full decade. Driven by Toronto, the Greater Toronto Area (GTA) is key to Canada's economic health, as TD Economics calculated, "that as much of one-quarter of Toronto's job creation over the past 20 years has flowed from the direct and indirect effects of the housing boom" ("GTA Housing" 1). Economists have ruled out the potential of a bubble burst in these leading markets, but anticipate some moderate correction over the next few years. RBC Economics reports, "local housing indicators continue to paint diverse pictures of vulnerabilities and risks across Canada; however, there is little indication that any major market faces a potentially destabilizing downturn in the near term" ("Canadian Housing" 1). In order to design the Growth Plan in a way that makes sense for the economic health of the region, demand and supply fundamentals need to be examined in the marketplace. The GTA housing boom has been met with some structural challenges that include deteriorating affordability, especially in ground-related housing, and a decreasing supply of serviced land and housing choice in the region. Therefore, there is an understanding that the market trends and forecasts in the GTA will be impacted by the role of Growth Plan and must be taken into consideration through the amendment process. 


\subsection{SUMMARY OF THE GTA HOUSING MARKET 2016 PERFORMANCE}

The following figure, adapted from the 2016 Altus Market Report, displays a snapshot of housing performance in the GTA for 2016.

Figure 1: Year of 2016 GTA Housing Performance Snapshot

\begin{tabular}{|c|c|c|c|c|c|}
\hline \multicolumn{3}{|c|}{ High-Rise New Homes } & \multicolumn{3}{c|}{ Low-Rise New Homes } \\
\hline Sales & Inventory $^{\star}$ & Average Price* $^{*}$ & Sales & Inventory & Average Price* \\
\hline 29,186 units & 11,792 units & $\$ 537 \mathrm{~K}$ & 11,7975 units & 1,878 units & $\$ 995 \mathrm{~K}$ \\
\hline $\begin{array}{c}\text { Increase } \\
\text { (Record High) }\end{array}$ & Decrease & $\begin{array}{c}\text { Increase } \\
\text { (Record High) }\end{array}$ & Decrease & Decrease & $\begin{array}{c}\text { Increase } \\
\text { (Record High) }\end{array}$ \\
\hline
\end{tabular}

Based on available product end of year

Changes in row three are compared from 2015 to 2016 year-to-year

Source: Altus Group, "State of the Market", 19

\subsubsection{Inventory}

Throughout the Growth Plan amendment process, available inventory has been a conversation sparked by many economists who argue that the Growth Plan is a contributing factor to a decrease in available inventory, especially low-rise homes, thereby triggering higher prices. TD Economics comments, " higher land costs and restrictive government regulations that have stretched out development project timelines to as much as seven years have made it increasingly difficult to supply housing at an affordable cost across the GTA" ("GTA Housing" 1). From the chart above, we can see that the there was a decrease in inventory both in high-rise new homes and low-rise new homes. In previous years, there was concern for the over-building of multiples in the GTA, especially Toronto, however, this is no longer a source of concern. The unabsorbed inventory fell from 0.58 units per 1,000 population in May 2015 (just over 20,000 units) to 0.20 units in November 2016 (just under 12,000 units), which is now within the "safe zone" (RBC Economics, "Canadian Housing", 9). On the other end of the spectrum, the inventory of low-rise new homes is a cause for concern. At year end, there was only

\section{Figure 2:}

Monthly Remaining New Home Inventory by Type Greater Toronto Area

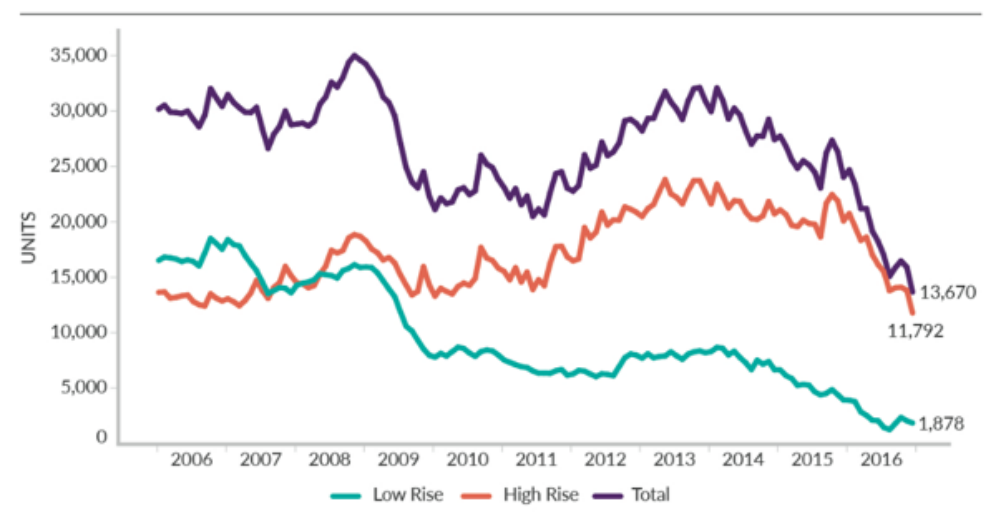

Source: Altus Group, "GTA Flash Report", 6 
1,878 units available, of which less than half of this total was single-detached homes, an extremely low number in historical terms. "Strong demand for low-rise product, combined with the lack of product available to purchase, pushed prices higher in 2016" (Altus Group, "GTA Flash", 6). Demand-supply tightness is corroborated by very low inventory of homes for sale in the resale market. "The number of months' inventory in Ontario is at its lowest point (1.8 months in December 2016) since records have been published by the Canadian Real Estate Association (2003)" (RBC Economics, "Canadian Housing", 6). In conclusion, the new homes sales market experienced a decline in inventory both in multiples and low-rise product.

\subsubsection{Sales}

Sales were strong in 2016 as "stretched affordability" does not appear to be a primary consideration for GTA homebuyers at this stage" (RBC Economics, "Canadian Housing", 8). In fact, total new homes sales in the GTA reached 47,161 units (the highest level in 14 years), with an estimated value of over $\$ 30$ billion (Altus Group, "GTA Flash", 6). With 29,186 high-rise sales, 2016 was a strong year breaking the previous sales record set in 2011. "About 9 in 10 high-rise sales were apartment units, with the majority of the remainder stacked townhouses (which reached a new high of 2,701 units)" (Altus Group, "GTA Flash", 6). Regarding the unit

\section{Figure 3:}

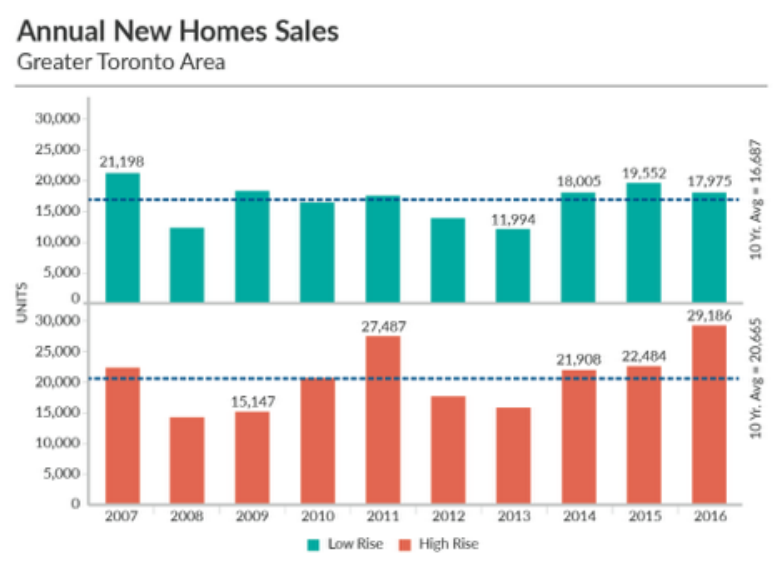

Source: Altus Group, “GTA Flash Report”, 6 type of high-rise product, "about 6 out of every 10 highrise sales were 1 bedroom plus den or 2 bedroom units, although 2 bedroom plus den and 3+ bedroom units have been capturing an increased share in recent years" (Altus Group, "GTA Flash", 6). Low-rise sales decreased to 17,975 units after increases in 2014 and 2015, due to a lack of available product. The decline in low-rise sales is attributable to single-detached and semi-detached units, while there was a modest pickup in townhouses. Overall, 2016 was still a strong year for sales in both markets. This is due to various reasons including supportive labour market conditions, low interest rates, and demographic fundamentals. "The rate of growth in adult population picked up from $1.6 \%$ in mid-2015 to $1.8 \%$ most recently", a good percentage to fuel the housing market (RBC Economics, "Canadian Housing", 9).

\footnotetext{
${ }_{1}^{1}$ Stretched affordability refers to the increasing difficulty for potential homebuyers to purchase a desired home due to the increasing price of low-rise and high-rise homes
} 


\subsubsection{Price}

With strong demand for new housing and decreasing supply, especially in the low-rise market, prices reached record highs in both the low-rise and highrise markets. In the high-rise market, the average price reached $\$ 537,000$ for 2016 . "Following several years of relative stability, the overall average price for available high-rise product moved up by $12 \%$ during the year, a combination of increases in average per square foot plus some increases in average unit size" (Altus Group, "GTA Flash”, 6). For low-rise product, the average price hit a record high of $\$ 995,000$, just shy of one million dollars and an increase in the overall low-rise price index of $20 \%$ during the year. Also, a lack of resale listings caused a spike in the resale price on sales. "Declining new listings and strengthening sales point to less movement among existing homeowners, and more activity among first-time buyers and investors" (CMHC, "Housing Market Outlook", 4). New sales follow the increase in price from the existing home market. The tight market conditions are fuelling the increase in price, far exceeding household income growth.

"Affordability in the GTA has been on a deteriorating trend since 2012 with the pace of deterioration accelerating since 2015" (RBC Economics, "Canadian Housing", 8).

The affordability issue is forcing many people to move further away from the GTA in search of homeownership. "Our [CMHC] evidence indicates that increasing single-family home prices in the GTA are motivating buyers to purchase more affordable homes in nearby centres like Hamilton, Barrie and Guelph. In turn, this purchasing behaviour is driving up house prices in these markets" (CMHC, "Housing Market Insight", 1). The constrained supply is a major contributing factor, especially for low-rise product. We can see that the supply of condos was quite high, and with steady demand, it was able to deliver to the market. This is reinforced by a statement from RBC Economics which states, "most of the affordability pressure is concentrated in the single-family home side of the market. Condominium affordability, on the other hand,
Figure 5:

Average prices of available inventory (2016):

GTA high-rise: $\$ 507,128$

GTA low-rise: $\$ 995,116$

Other GGH high-rise: $\$ 401,552$

Other GGH low-rise: \$537, 244

Source: Altus Group, "State of the Market”, 60 
is much less strained, as the level is only modestly higher than its long-term average" ("Canadian Housing", 8). The affordability challenge has begun to not only impact the low-income population, but also the higher income levels and those in homeownership, thus creating a more widespread affordability issue. This is attributable to higher land costs and restrictive government regulations pushing development into built-up areas with highly valuable land among other things. A second issue identified in the GTA market is a shrinking diversity of housing stock. Again, this is an issue that can be made worse by the anticipated direction of the Growth Plan. There has been an increase in condominiums and smaller lot sizes, leading to a price premium for townhouses and singledetached units. "While increased densification has been a laudable goal of the provincial and municipal governments in recent years, it can reasonably be argued that the pendulum has swung too far in favour of units that are typically tailored for shorter-term living" (TD Economics, "GTA Housing", 2). This also raises concerns when the future demographics of cities are taken into consideration (discussed in Section 4.5).

\subsection{FORECAST FOR THE GTA HOUSING MARKET}

The following figure, adapted from the 2016 Altus Market Report, displays a 2017 forecast for housing performance in the GTA.

Figure 6: 2017 GTA Housing Forecast

\begin{tabular}{|c|c|c|c|}
\hline \multicolumn{2}{|c|}{ High-Rise New Homes } & \multicolumn{2}{|c|}{ Low-Rise New Homes } \\
\hline Sales & Average Price* & Sales & Average Price* \\
\hline $\begin{array}{l}\text { Inventory constraints and } \\
\text { mortgage qualification } \\
\text { changes will bring sales } \\
\text { below peak levels }\end{array}$ & $\begin{array}{l}\text { Positive growth but slower } \\
\text { than } 2016 \text { - unless } \\
\text { inventory becomes } \\
\text { constrained }\end{array}$ & $\begin{array}{l}\text { Sales volume tied to new } \\
\text { product launches, } \\
\text { anticipated to remain tight }\end{array}$ & $\begin{array}{l}\text { Tight supply and low } \\
\text { resale inventory will } \\
\text { continue to push prices }\end{array}$ \\
\hline Decrease & Increase & Remain level & Increase \\
\hline
\end{tabular}

\footnotetext{
Changes in row three are compared from 2016 to 2017 (forecast) year-to-year Source: Altus Group, "State of the Market", 98
}

The near term housing forecast for the GTA remains positive. There has been some speculation regarding a bubble burst in the housing markets for Toronto and Vancouver, however, many economists argue this will not occur. In the housing market outlook for the GTA, CMHC reports that price growth is expected to moderate by 2018, but demand for housing will remain strong due to factors such as demographic shifts, improving labour market conditions, and net migration (CMHC, "Housing Market Outlook", 2). To comment further, TD Economics identifies three factors that are restricting the housing market from slackening over the near term. First, it is expected that Toronto will experience an increase in foreign investors moving from B.C. to Toronto due to the 
recent restrictions imposed on foreign investment in B.C. Second, Toronto's market has been slow to respond to the restricted supply issues. This has led to an identified 'buyer's gridlock,' "whereby rising premium of prices on upper-end homes has limited the options available to move up buyers and reduced churn in the marketplace" (TD Economics, "Regional Housing", 3). In addition to a lack of resale supply, there has also been a constrained supply of new construction. "The Toronto market continues to register an elevated number of units under construction, but lengthy permitting processes and infrastructure deficiencies have slowed the rate at which starts are translated into new completions" (TD Economics, "Regional Housing", 3). Last, "the Toronto market has exhibited significantly less price appreciation on a quality-adjusted basis over the last three years, suggesting less room for a near-term correction" (TD Economics, "Regional Housing", 4).

In the high-rise market, sales are projected to decrease slightly. Based on projections by Altus Group, "2017 completions are expected to push above the 22,000 mark in 2017 and higher still in 2018 (with a new record possible given the number of units already under construction)" (“GTA Flash" 6). The increase in sales will occur alongside an increase in price. High-rise prices are expected to increase at a slower rate than 2016, however, if the inventory is constrained due to lengthy completion time, prices will accelerate faster. In the low-rise market,sales are expected to remain consistent with sales levels of 2016. They are linked to the number of anticipated
Figure 7: GTA AVERAGE HOME PRICES

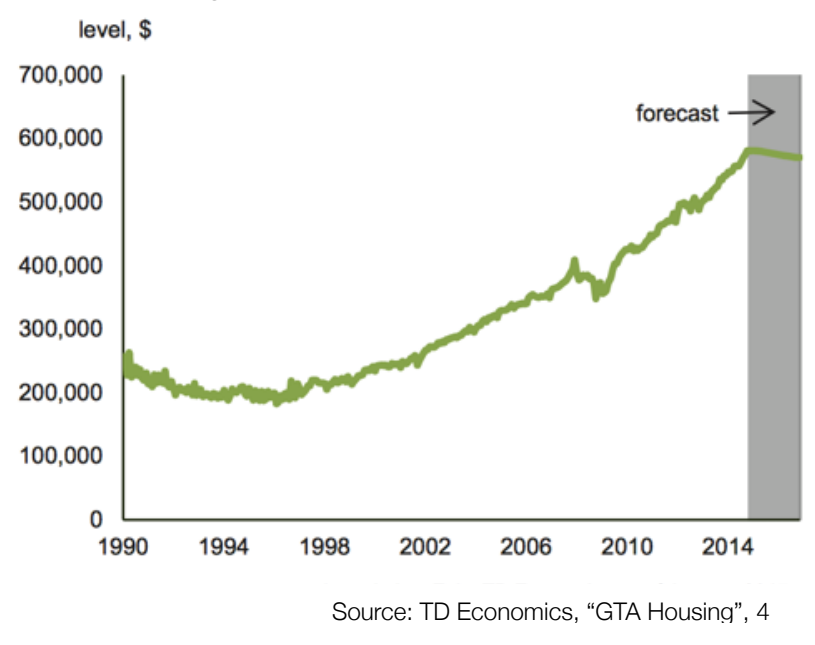
new product launches. GTA homebuilders have responded to historically low levels of single-family home supply in 2015, with starts rising in 2016 . This will help to address the demand-supply tightness in this category. However, "inventories of newly completed and unsold single-family homes continue to be historically low despite trending slightly higher in the past four years" (RBC Economics, "Canadian Housing", 9). This suggests that prices will continue to rise. RBC Economics comments, "policy to reduce urban sprawl and favour higher density urban development contributed to a significant slowdown in singledetached home construction since the mid-2000s" (RBC Economics, "Canadian Housing", 10).

Given this forecast for the near term, proposed amendments to the Growth Plan advocating for higher density and intensification will further exasperate the tightness of demand-supply in the GTA further deteriorating affordability in the region. The province has attempted to address the issues of affordability by announcing changes aimed at ensuring homebuyers aren't taking on bigger mortgages than they can afford if interest rates were to increase. However, despite the announcement in the Fall of 2016, there was no retreat in home buying intentions in the GTA - either among current homeowners or current renters. "The tighter mortgage insurance rules would directly apply 
only to a subset of buyers. For example, looking at recent new home buyers in the GTA, about 2 out of every 3 end user buyers either didn't require a mortgage, or put down at least 20\%" (Altus Group, "GTA Flash", 7).

Overall, the Ontario housing market is experiencing increasing prices, especially in ground-related housing. This is being felt by a wide spectrum of income levels. As we move forward in the review process of the Growth Plan, it is imperative to use the current and forecasted market conditions as a piece of the decision making process. The Growth Plan plays a major role in determining where growth will occur and as such must consider the economic outcomes of that role. 


\subsection{REVIEW OF THE GROWTH PLAN FOR THE GREATER GOLDEN HORSESHOE}

\subsection{INTRODUCTION}

The Growth Plan for the Greater Golden Horseshoe was first enacted in 2006 by Dalton McGuinty's Liberal Government. Regional planning took a backseat to localized planning through the mid 1970s and much of the 1980s in Ontario. However, as the conversation on environmental issues, transportation, and infrastructure began to grow amongst experts, the public, and politicians, regional planning and coordination amongst municipalities reemerged. Harris' 1995 Conservative government enacted the 2002 Oak Ridges Moraine Conservation Plan and initiated a program of Smart Growth for Ontario. This work on Smart Growth was carried over into the eventual passage of the regional planning program of the McGuinty Liberal government in 2004. "First came the creation of an extensive regional Greenbelt, then passage of the Places to Grow Act in 2005, and then in June 2006, the release of the 'Growth Plan for the Greater Golden Horseshoe,' the first regional plan for the Toronto Metropolitan Region in more than 30 years" (White 44).

The province is now undergoing the first ten-year review of all provincial land use regulation plans, including the Growth Plan. The true economic and social implications that occur from policy are often not realized for a long period of time. Given that the Growth Plan is under its first review, the time-frame must be considered, and the potential for these implications to grow in time must be studied. Both the 2006, and proposed Growth Plan, lack adequate consideration of market forces. "Land use planning is intended to lead to better quality of life and living conditions by encouraging a better urban form, a more efficient pattern of development, enhancing the environment, minimizing externalities, etc. However, there may also be unintended impacts of this land use planning process which should be considered in making policy decisions about the type and magnitude of land use regulation imposed" (Amborski and Clayton i). Ontario's Greenbelt is the largest permanent greenbelt in the world, stretching over 7,200 square kilometres of land. The review process, therefore, needs to be taken seriously and we must understand that the consequences it produces can grow with time.

\subsection{INTENTION OF THIS REVIEW}

The intention of this MRP is not to suggest that there should not be land use regulation, but rather that all benefits should be studied, along with the unintended costs that this type of regulation has on the economic environment of the GGH. This period of review is an opportunity to recognize these costs, and propose amendments that will help to mitigate these effects and create a better balance between the economic, social, and environmental goals of the province. 


\subsection{EVIDENCE OF THE ECONOMIC IMPACT OF THE GROWTH PLAN}

As it was outlined in Section 3.0 of this paper, Ontario's housing market is experiencing affordability challenges forecasted to continue over the near term. This increase in price relative to income is creating great difficulty for the low-income population, but also now for the middle and higher income brackets and those looking for home ownership. It has been argued that the Growth Plan does not have a large impact on housing affordability, but instead it is other factors that are resulting in a lack of affordable houses. While it is true that numerous issues play a role in the housing market, there is enough evidence to infer that the Growth Plan for the GGH does in fact, impact Ontario's housing market.

Economics 101 teaches us that when supply is constrained, and demand is strong, prices rise. Together, the Growth Plan and the Greenbelt create a restriction on developable land. The Greenbelt, by its very nature, takes a large portion of land in the GGH and protects it from development. The Growth Plan then directs growth into land designated as the built-up area. As we can start to see, there is a restriction on the supply of land and, inevitably, this affects demand and supply of housing.

This pattern of decreasing affordability as a result of land use regulation, growth management, and smart growth policies have been identified by various planning professionals and economists. Ryerson's Centre for Urban Research (CUR), comments, "Any consideration of economic costs are absent from both the current 2016 Growth Plan and the proposed Growth Plan. The economic costs with the greatest negative impact which will worsen as the years pass come from the deliberate intent of the plan to suppress the supply of new ground-related houses (singles, semis, and townhouses) while encouraging apartments. Given the strength of the underlying preferences for ground-related forms of housing, the end result is higher and higher prices of ground-related houses (both existing and new). This continued deterioration in affordability has serious negative implications for economic and productivity growth in the Greater Golden Horseshoe" (Amborski and Clayton i).

The Growth Plan is relatively new in its implementation and it is therefore useful to consider how these policies have impacted the economic environment in other areas. "Over the last 20 years, land supply has emerged as an important concern across a number of broad land use planning exercises in North America, Britain, and New Zealand. These include plans that fall under the titles of 'growth management', 'urban containment' and 'smart growth', all of which share similar regulatory constraints. Land and housing supply concerns have been identified by a number of planners and economists who have analyzed these plans" (Amborski and Clayton 5).

Paul Cheshire, Max Nathan and Henry Overman recently published a book that uses the London Greenbelt policy as an example of how land use regulation impacts the urban economics of the area. "Since [land use planning] policy intentionally and very firmly restricts the land for housing or any other urban development it is no surprise that the supply of housing has become progressively more inelastic. Houses that provide more space and a greener environment cannot be built without land on which to build them; and our system both explicitly and implicitly (by reason of how it is controlled and as a result of the incentives it has thrown up) drastically rations such space" (Cheshire et al 83). 
In New Zealand, land use regulation has created similar housing affordability issues. "Constraints on the release of land and development capacity (within and on the edge of cities) creates scarcity, limits housing choice, and increases dwelling prices. These impacts are disproportionately felt by people of lower incomes" (New Zealand Productivity Commission, "Housing Affordability", 9). Land use planning in New Zealand is undergoing an inquiry to create a land use regulation system that supports desirable social, economic, environmental and cultural outcomes. The Productivity Commission have looked into the intention and the goal of land use planning, and discusses, "how councils can face an 'objective overload' and conflicting goals that distract from the critical purpose of land use planning - providing sufficient development capacity to meet demand" (New Zealand Productivity Commission, "Better Urban Planning", 33).

Further, similar policy in Seoul has also been studied to understand the economic impact. For example, ChangMoo Lee takes an economic approach in his paper. He finds that the Greenbelt as a "land use regulation generates both social costs due to its land-supply restriction effect and social benefits due to its amenity effects" (Lee 42). In his paper he then measures these effects using an inter-temporal efficiency test. He shows "empirically that releasing a one-kilometre band of land from the inner edge of the greenbelt in Seoul would lower land rents and housing prices inbound of the greenbelt 7.7 percent and 2.7 percent, respectively" (Lee 42).

Last, land use regulation has been implemented in various states in the U.S. as an attempt to control growth as well. The study of how these policies have impacted the economic environment of the cities the policies manage have become a growing topic among professional planners and economists. Casey Dawkins and Arthur Nelson have examined the effect of urban containment policies from an economic perspective in various American cities. They conclude, "that urban containment programs do affect land prices, and that housing producers do not always respond to higher land prices by increasing the density of development. In relation to aggregate housing prices, the effects of urban containment policy depend on factors such as style of policy implementation, local housing markets, and pattern of land ownership" (Dawkins and Nelson 1). Gerrit Knaap has also demonstrated the importance of land monitoring to mange supply in the presence of urban containment policies. He points out that "a central problem in growing smart is how to accommodate market forces while preventing the spoil of sprawl. Progress toward resolving this problem, however, can only be made with sound and current information about the supply of and demand for land" (Knaap 2). This further highlights the importance of the design of the Growth Plan to mitigate the economic consequences through this review process. Another report from the White House also identifies barriers, "including land restrictions that make developable land much more costly than it is inherently," as contributing to the "growing severity of undersupplied housing markets jeopardizing housing affordability" (The White House 2).

We will now look specifically at the economic consequences of Ontario's proposed Growth Plan. As evidence from various locations worldwide demonstrates, it is no longer a fitting argument to say that there is not enough evidence to show that growth management, smart growth and urban containment plans play a role in the decreasing affordability of housing. 


\subsection{ECONOMIC CONSEQUENCE \#1 - LAND SUPPLY AND HOUSING AFFORDABILITY}

\subsubsection{Supply of Serviced Land}

The issue of restricted supply of land for development purposes is one of the major economic consequences of the Growth Plan, leading to issues of housing affordability across the GGH, especially in the GTA and for groundrelated housing. "Prices are determined by the intersection of supply and demand. In the GTA, the sizeable number of people ${ }^{2}$ who come to the region each year cause an increase in housing demand, and this household formation puts upward pressure on prices. Economic theory would expect that the supply would respond to meet this growth in market need thereby moderating price increases. However, we continue to see dramatic increases in prices, especially for ground-related homes" (Amborski 1). As this is clearly an issue on the supply side, it warrants investigation into its relationship with rising housing prices.

In October 2016, the Neptis Foundation released a report looking at the supply of land available for the GGH. "The Neptis researchers have estimated that only about 10,800 of the 56,200 hectares [located in the inner ring] was developed between 2006 and 2016; less than 20\% of the total supply. That leaves $80 \%$ of the designated land supply to accommodate another 15 years' worth of growth to 2031 and possibly beyond." (Neptis Foundation, "No Shortage"). This finding would indicate that there is plenty of land available for growth. Neptis researchers further comment, "during the public consultation into the 10-year review of the Growth Plan for the Greater Golden Horseshoe, some commentators suggested that provincial land use policies have created a land supply shortage responsible for rising housing prices in the Toronto region. Neptis research shows that, on the contrary, there is plenty of land to accommodate new communities at the urban edge until at least 2031 and possibly beyond. There is no 'shortage' of land supply" (Neptis Foundation, "No Shortage"). However, in using the definition of total land supply as all the physical land in the region not dedicated for non-residential uses, the Neptis Foundation fails to consider the land that can actually be used for development in the near term. A policy report released by CUR, "argues that a shortage of serviced land is the major contributor to a marked decline in the production of new ground-related homes in the GTA thus contributing to the sharp rise in prices" (Clayton, "Why there is a Shortage", 1). It is therefore imperative to consider the supply of serviced land rather than the total supply of designated land when considering the impact of supply in the marketplace.

By definition, serviced land refers to the external servicing and committed investments to servicing provided by the municipalities. It also considers the necessary planning approvals that must be in place prior to any development occurring. Professor David Amborski, clearly states, "land use regulation does have impacts on the price of housing" (Amborski 1). He then argues that the definition of land supply is important. "Not all 'designated land' is available to produce new housing units in the short, or even medium term. The reason for this is that land must be serviced and have the necessary planning approvals (subdivision, zoning, and building permits) prior to being built upon" (Amborski 2). The supply of housing must be more flexible in responding to the year-to-year demand. As many economists have noted, land use regulation inevitably has an impact on housing prices.

\footnotetext{
2 The GTA is projected to be the fastest growing region in Ontario, with its population increasing by over 2.8 million, to reach almost 9.5 million
} by 2041. (Ontario Ministry of Finance) 
Many proposed amendments to the Growth Plan will have the effect of further restricting the supply of housing. Barriers to the supply of housing include a lack of servicing capacity and infrastructure investment, and lengthy development approval processes. "OHBA is concerned that a number of proposed amendments to the Growth Plan, as well as a lack of clear transition policies may in fact slow down municipal planning processes and the delivery of critical infrastructure, by jeopardizing the implementation of Secondary Plans and other projects currently underway could translate into even more significant delays in an environment where we are all having challenges with implementation under the current 2006 Growth Plan" (OHBA 25). Further, with the proposed density and intensification targets of 80 people and jobs/hectare and 60\% intensification, many municipalities would need to receive provincial investment to ensure that the increased density can be supported by transit and services. For example, the City of Hamilton notes that "it is important that the Province provide a long term sustainable funding model to ensure that the full range of 'hard' and 'soft' infrastructure and services are provided to sustain the transit supportive community envisioned by the Growth Plan" (OHBA 26). The Crombie Report outlines various concerns from development companies who face a number of challenges when building in intensifying areas. "These include some of the requirements of the Building and Fire Codes, difficulties in obtaining appropriate rezoning, parking requirements, and the costs of downtown taxes and development charges" (Advisory Committee 63). The proposed Growth Plan has the potential to further restrict the groundrelated housing supply, and therefore these concerns must be addressed before anything is approved.

Municipalities are required by the Provincial Policy Statement (PPS) to "maintain at all times where new development is to occur, land with servicing capacity sufficient to provide at least a three-year supply of residential units available through lands suitably zoned to facilitate residential intensification and redevelopment, and land in draft approved and registered plans" (Ministry of Municipal Affairs and Housing 14). Further, the minimum threeyear requirement is to include a full range and mix of housing types and densities. However, "none of the GTA regions appear to be keeping track of their supply of land with servicing capacity for ground-related housing in relation to projected PPS requirements on a regular basis" (Clayton, "Why there is a Shortage", 7). It is recommended that the province and municipalities immediately commence an inventory of the short-term land supply in relation to projected demand and supply. Without doing so, the impact of the proposed Growth Plan, on the already limited supply of serviced land, cannot be fully understood.

\subsubsection{Static Built Boundary}

A second economic consequence that contributes to a limited supply of land and decreasing affordability is the delineation of the built boundary within the Growth Plan. The built boundary was finalized in 2008 , identifying the areas targeted for development. It acts as an implementation and monitoring tool for the Growth Plan by identifying the area that must meet intensification and density targets for each municipality. There are numerous issues with the built-boundary in relation to the proposed Growth Plan that are concerning for the economic health of the GGH. 
Figure 8: The Effect of Achieving 80 people + jobs/hectare

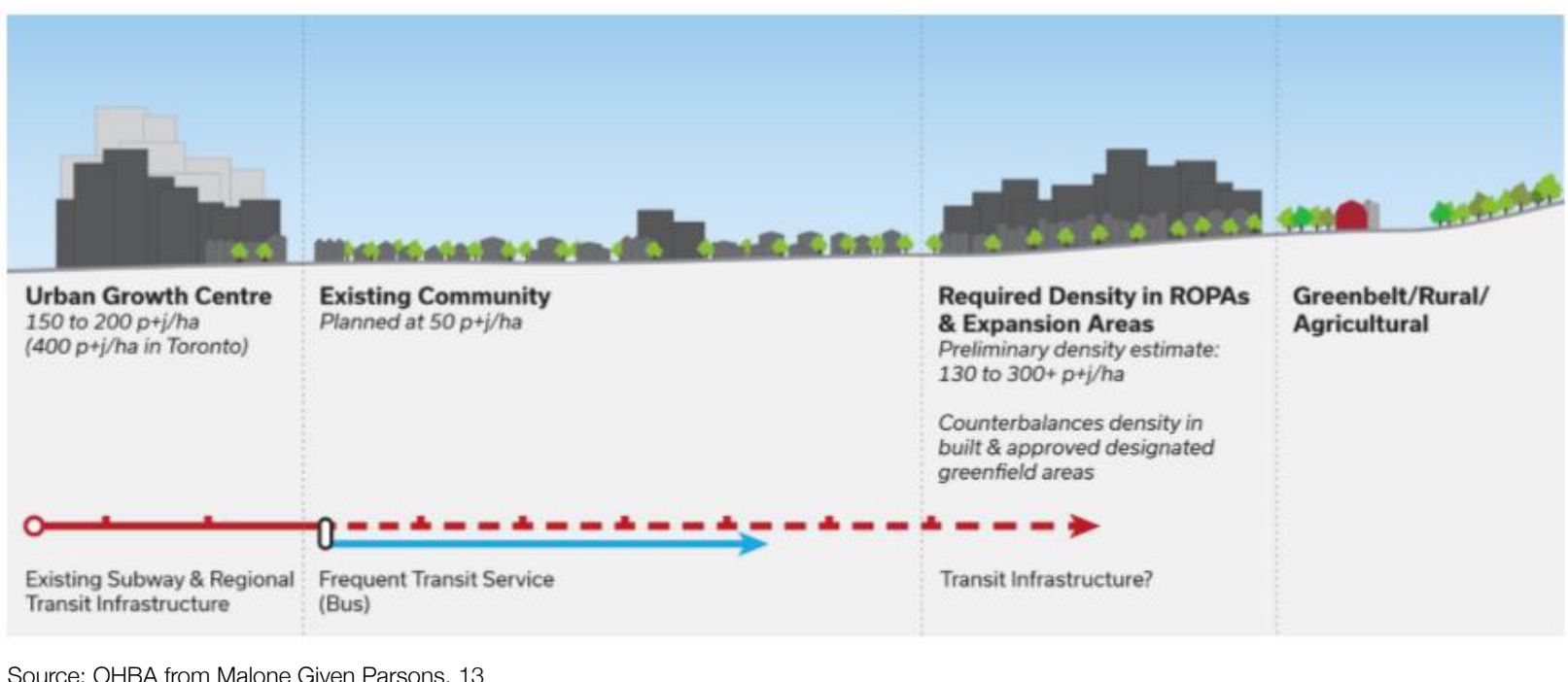

To begin, the boundaries for the built-up area were first introduced with the creation of the first Growth Plan and finalized on April 2, 2008. Despite development that has occurred to date, the amendments for the proposed Growth Plan released by the province do not make any changes to the built boundary. The argument is that municipalities still have enough space within the 2006 built boundary to accommodate projected population and employment numbers at proposed intensification and density targets. In the previous Growth Plan, municipalities were required to reach a density of 50 people and jobs per hectare and intensification of $40 \%$. It is now being proposed that the requirement be increased to 80 jobs and people per hectare and $60 \%$ intensification. This is a large jump, especially for some of the smaller and more suburban municipalities. Without extending the built boundary, many municipalities are forced to use the limited space they have to achieve these new targets. The Building Industry and Land Development Association (BILD) has clearly outlined what this change will mean for some municipalities with work completed by Malone Given Parsons Ltd. With many GTA communities being closer to the current Growth Plan target of 50 residents and jobs per hectare, the remaining designated greenfield areas are in a position of having to overcompensate at higher density rates in order to achieve the new targets. "The background data provided by OGS [Ontario Growth Secretariat] in the Performance Indicators presented a DGA [Designated Greenfield Area] absorption rate ranging from 2.6\% to 6.7\% in 2011, but as the regions and municipalities have presented in their professional planning staff reports, the new communities committed to through the 2006 growth plan conformity process are as high as 84\% (Region of Peel Report)" (OHBA 20). Figure 8, above, by Malone Given Parsons Ltd. demonstrates the effect that overcompensating density on the remaining designated greenfield areas would result in.

The highest density would be pushed to the urban periphery where there is less access to the infrastructure and services needed to support such density. Additionally, by not updating the built-boundary, development and approved development projects that have occurred over the past ten years have not been included. To ignore these new projects, ignores evidence-based planning that should be used in the review process of the Growth Plan. 
Further, with the limited supply of designated land, there is an adverse effect of people seeking homeownership outside of the $\mathrm{GGH}$. Many people moving further away from the GGH are doing so in order to find affordable ground-related homes. With municipalities needing to over-compensate and forcing higher densities on the periphery of the built boundary, they are not addressing the demand for ground-related homes. In 2016 groundrelated housing starts outside the Greenbelt (the "Outer Ring") increased by 7.3 percent year-over-year following double-digit increases in 2014 and 2015 (Clinkard). "As a result of this upturn in starts over the past three years, the volume of ground-related units under construction in this area has risen by almost 60 percent, more than twice the 26.5 percent rise in ground-related dwellings under construction within the Greater Toronto/Hamilton Area" (Clinkard). This issue, "clearly reinforces the view that the extremely limited supply of affordable groundrelated dwellings within the GTHA is encouraging more buyers to migrate to the Census Metropolitan Areas within the GTHA's commuter shed" (Clinkard). This trend is an economic consequence of the Growth Plan, that will be made worse by the increase in the proposed intensification and density requirements, especially without any adjustment to the built boundary.

It is recommended that the province update the built boundary to 2016 conditions and leave density and intensification targets as is with an option for municipalities to increase them if they see fit.

\subsection{ECONOMIC CONSEQUENCE \#2 - LACK OF HOUSING CHOICE}

"This Plan is about accommodating forecasted growth in complete communities, whether urban or rural, existing or new. These are communities that are well designed to meet people's needs for daily living throughout an entire lifetime by providing convenient access to an appropriate mix of jobs, local services and a full range of housing to accommodate a range of incomes and household sizes" (Ministry of Municipal Affairs and Housing 6).

The above quote is taken directly from Section 2.1 of the proposed Growth Plan which discusses the vision of the plan. One of the highlighted components of this definition is a full range of housing to accommodate a range of incomes and household sizes. The current policy direction of the Growth Plan, when operating in conjunction with market forces, is leading away from this vision of complete communities that accommodates a range of people through a spectrum of choice. We have seen that affordable housing is a prominent issue not just for the lower income brackets, but now for the middle income population as well.

At a high-level the Growth Plan is a land use planning tool. The New Zealand Productivity Commission reminds policymakers and government authorities that the primary objective of land use planning is to provide land to meet demand. This objective cannot be forgotten in the design of the Growth Plan. "Commentators sometimes urge local authorities to consider the potential effects of urban land use planning on outcomes such as reducing obesity rates, carbon emissions or crime. Yet these issues are not central to the purpose of urban land-use planning.

From a national perspective, neither is urban land-use planning the best or even a significant policy instrument for 
improving many of the outcomes across this diverse range of issues" (New Zealand Productivity Commission, "Better Urban Planning", 33). There is an opportunity through this review process for the Growth Plan to better understand the market and what it demands. This includes understanding the type of housing that people in the GGH desire, and also where land uses should be designated based on where people would like to work and live, rather than dictating where this needs to be.

There has been an increase in the price of ground-related housing attributable to various factors including the Growth Plan. "During the past 10 years the average asking price of new ground-related housing (singledetached, semi-detached and townhouses) being marketed has almost doubled to $\$ 738,731$ in the first quarter of this year, according to RealNet Canada's Price Index" (Clayton, "Why there is a Shortage", 1).

As municipalities, directed through provincial policy, push for greater densities and intensification, land available for ground-related housing is becoming more sparse pushing prices up. "According to RealNet, the remaining (unsold) inventory in ground-related housing projects which are being marketed in the GTA fell to a record low in the first quarter of this year" (Clayton, "Why there is a Shortage", 2). This drop in inventory further demonstrates the decreasing supply, and the responding increase in prices. This begins to show how the fullrange of housing is being limited by implementation of the Growth Plan.

\section{Figure 9:}

Increases in Average Sale Prices of New and Resale in Ground-Related Housing in the GTA, 2005-2015

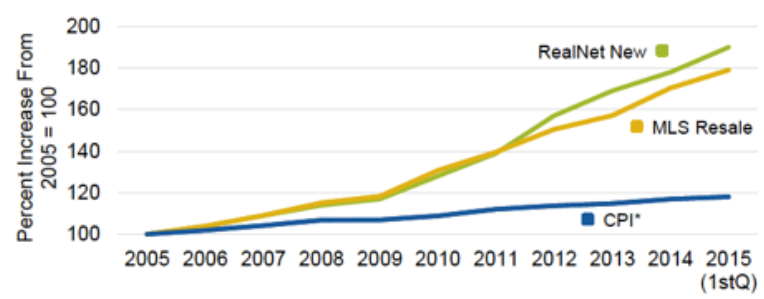

- $\mathrm{CPI}=$ Consumer Price Index Source: RealNet Canada Inc., TREB and Statistics Canada

Source: Clayton, "Why there is a shortage", 1

\section{Figure 10:}

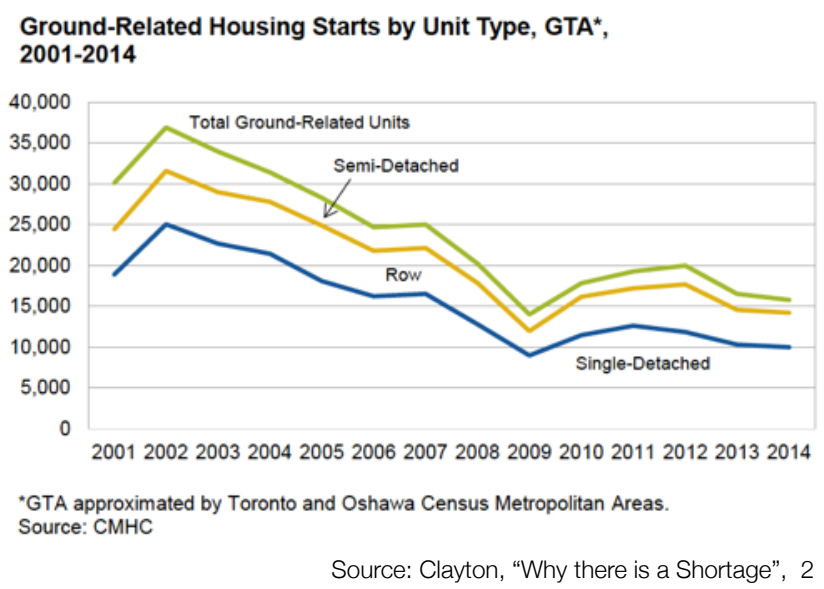


Malone Given Parsons Ltd. highlights how many municipalities will see a sharp change in built form as a result of the increased density and intensification requirements of the proposed growth plan. In a presentation in September of 2016, Don Given presented the following image:

Figure 11: What does 80 people + jobs/hectare look like?

\section{People \& Jobs/ha Scenario}

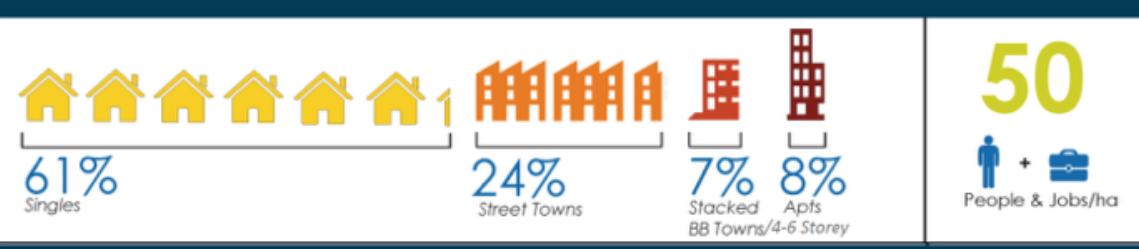

\section{People \& Jobs/ha Scenario}

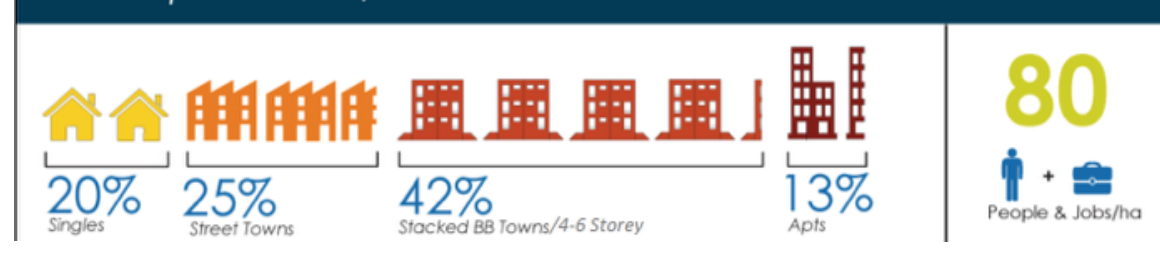

Source: Malone Given Parsons, 18

It is clear that the built form will change and the range of housing will become limited. Those looking for more space for growing families will be priced out of the market and housing typology will become more repetitive.

Further, there is an argument that many people in the GTA are willing to live in apartments and condominiums within compact neighbourhoods and forgo groundrelated homes. However, in August of 2016, CUR conducted a research report that proved "the view that many households in the GTA would willingly give up single-detached houses to move into higher density housing in location-efficient communities is wrong" (Clayton, "Will GTA Homebuyers", i). Three consumer surveys, TREB Survey, 2015, REMAX Hallmark Home Buyer Survey, 2015, and Canadian Home Buyers Preference Survey, 2015, for the GTA indicate that the demand for ground-related housing remains strong. For example, the TREB Survey found that "single-detached homes were the most common
Fig 12:

rrererrea nousing Type of Prospective Buyers, GTA, November 2015

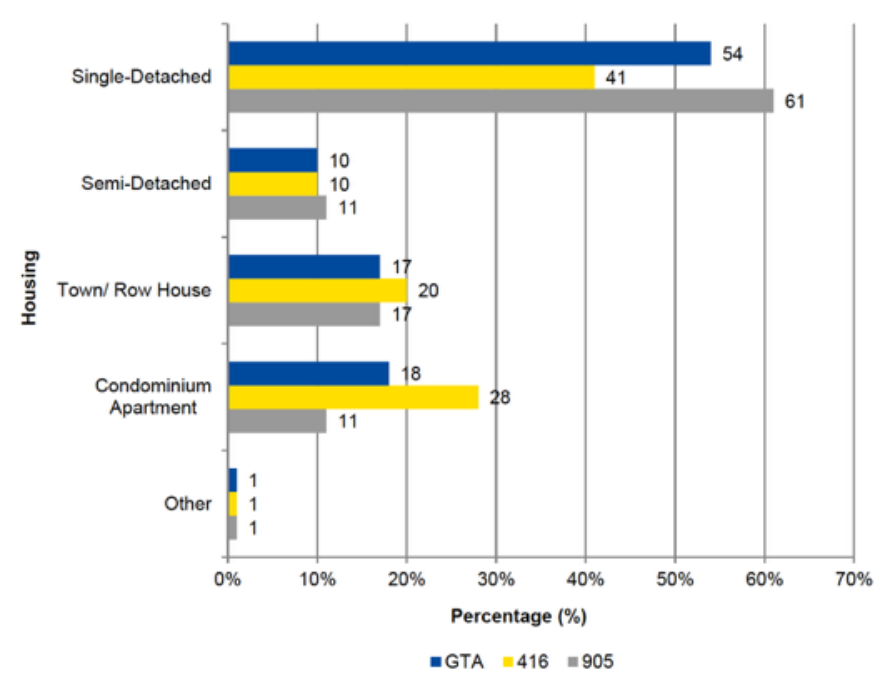

Source: Clayton, "Will GTA Homebuyers, 10 
type of housing that prospective buyers intended to purchase - 54\% of intending buyers in the GTA. Condominiums and apartments second; however, only $18 \%$ of intending buyers in the GTA and $28 \%$ of intending buyers in the City of Toronto favoured them" (Clayton, 2016, 16). The REMAX Hallmark Home Buyer Survey found similar results, documenting that $69 \%$ of respondents indicated a single-detached house as their preferred type of housing (Clayton, "Will GTA Homebuyers", 11).

Interestingly, millennials (ages 18 to 34), the next cohort entering the home ownership market, preferred groundrelated homes as well, especially single-detached. In the TREB Survey of potential first-time buyers, $75 \%$ of respondents stated their intention to buy ground-related housing (Clayton, "Will GTA Homebuyers", 13). The GTA housing market is increasingly difficult for this specific market. When we look at the demographic trends that will take place over the near term, a large portion of the population will be in the market to buy, however, are not able to do so because of the unaffordable prices. As demonstrated, the amendments to the Growth Plan will further restrict supply of housing, pushing prices for single-detached homes in the GTA above $\$ 1$ million as we have seen in 2017. With these increasing prices, housing choice also becomes more homogenous. Homebuyers should be able to choose the home that is right for them. A large portion of the GTA is entering a stage in life where families will begin to grow in size. Therefore, small apartments that can be afforded by these families are not an adequate housing choice for many. Many proponents of the proposed Growth Plan have argued that there is nothing wrong with limiting the amount of detached and semi-detached homes. They argue that towns and apartment/ condominium style housing are an efficient form of housing that will achieve complete communities. However, they fail to represent the definition of complete communities that allow for a full range of housing.

The difficulty that first time buyers are experiencing has been identified by the province as well. In November 2016, the province released an announcement proposing to double the maximum Land Transfer Tax refund for first time homebuyers from $\$ 2000$ to $\$ 4000$. This is a step in the right direction, however it ignores one of the significant causes of the problem. The province needs to consider how supply of desired ground-related housing can be increased in order to address one of the causes of the increasing prices.

The proposed Growth Plan is clear about its goal and vision for complete communities. It is necessary that we consider how the amendments to the Growth Plan will impact the housing market and move away from the elements of the definition for complete communities. As the demographics of Ontario will change in the coming years, we must plan ahead and ensure that there is housing available to accommodate the changing composition of the population. It is also important that we consider the character of existing municipalities and offer options for the population across all income brackets. 


\subsection{ECONOMIC CONSEQUENCE \#3 - IS A ‘ONE-SIZE FITS ALL’ APPROACH APPROPRIATE?}

Currently, the Growth Plan for the Greater Golden Horseshoe applies a standard target for intensification and density to all municipalities that it applies to. Given the expanse of land that it controls, there needs to be a more specialized approach to applying appropriate targets for each individual municipality. "The GGH covers almost 31,000 square kilometres and includes large cities, rapidly growing suburban municipalities, mid-sized centres, small towns and villages, and rural areas" (Allen and Campsie 4). In an effort to retain the character and diversity of the GGH, intensification and density need to support each municipality to ensure that the goals for growth remain attainable. The Greenbelt covers 7,200 square kilometres of the GGH, yet the adverse economic effects of the smart growth tactic are not fully understood. As such, it is imperative that this conversation is had before any amendments to the Growth Plan are finalized. The GGH consists of a total of 110 separate municipal jurisdictions each with their own pattern of demographics, built form, and lifestyle. Imposing a "one size fits all" approach to the Growth Plan is therefore not acceptable.

Figure 13 below, from Malone Given Parsons Ltd., illustrates the challenge of a 'one size fits all' approach to density and intensification targets.

Figure 13:

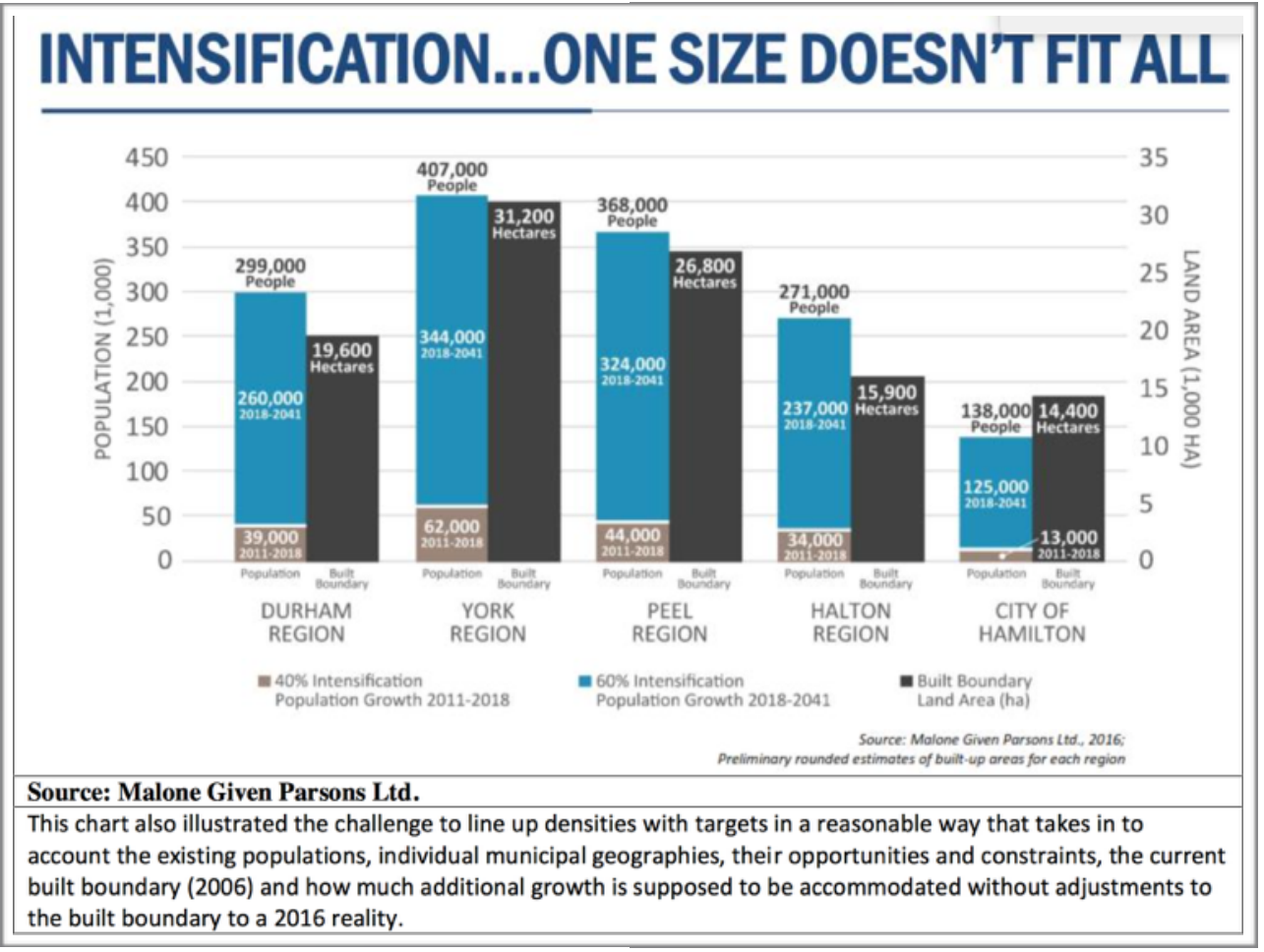

Source: OHBA from Malone Given Parsons, 18 
The proposed intensification target of $60 \%$ from $40 \%$, and density target of 80 people + jobs per hectare from 50 people + jobs per hectare is impractical for many municipalities. "The local municipal circumstances differ from municipality to municipality, especially with respect to servicing infrastructure and higher-order transit” (OHBA 16). For municipalities further away from Toronto, increased density can simply not be supported at this time. It is recommended that that a more targeted approach to intensification and density targets be applied. OHBA recommends that the province recognize and differ between municipalities that (18):

- Are built or nearly built out

- Have existing or planned/funded higher order transit lines

- Have an Urban Growth Centre (UGC)/ Do not have an UGC

- Outer Ring vs Inner Ring

- Water/ Wastewater Infrastructure Capacity

By realizing these key differences between municipalities, the province will be better able to apply reasonable and achievable growth targets. Three key differences between municipalities to draw attention to are infrastructure capacity, geographic location and planned/funded higher order transit.

Infrastructure Capacity: As discussed earlier, there is a lack of supply of serviced land in many suburban areas. Development charges to pay for growth are already increasing at a pace that is becoming troublesome for the development industry, especially outside of Toronto. Without serviced land, the density sought by the province can simply not be achieved. Another issue has to do with municipalities planning for $40 \%$ intensification in previous years. Without moving the built boundary, some municipalities have an issue with increasing intensification in the limited space that they have left. This means, that in order to achieve intensification and density targets, they must over-build in areas closer to the built boundary edge where servicing and access to transportation are lacking. Overall, there has to be a financial response from the provincial and federal government if higher density is to be supported in many of the more suburban municipalities.

Geographic Location: Municipalities across the GGH vary greatly in size, population, and built form. This is especially true in comparison of outer and inner ring municipalities. The Growth Plan organizes municipalities into the Inner Ring and the Outer Ring. "The Inner Ring municipalities are the largest, fastest-growing and most urbanized municipalities in the GGH" (Allen and Campsie 6), including the cities of Toronto and Hamilton and the Regional Municipalities of Halton, Peel, York, and Durham. These municipalities generally experience greater densities and have adapted to address increasing populations over the past decades. Still, within the inner ring, there are great differences between municipalities. For example, the City of Toronto has a population density of 4,149.5 people per square kilometre whereas Halton Region has a density of 520.4 people per square kilometre. The Outer Ring, generally, "is less urban, less dense, and less populated and, with some important exceptions, is experiencing less growth pressure compared with the Inner Ring" (Allen and Campsie 6). The outer ring includes counties such as Brant and Dufferin, cities such as Barrie and Guelph, and the regional municipalities of Niagara and Waterloo. There is some increased pressure on places such as Waterloo from people who are being priced 
out of the GTA, but these communities are often less dense than those in the inner ring. To expect the same intensification and density targets from places like Toronto and Guelph is unreasonable.

Transit: Without proper transit in place, increased density, again, cannot be supported. One of the major updates to the Growth Plan is the introduction of density targets for major transit areas. How density targets will be implemented at the local level is a challenge that needs to be addressed. "The new density targets apply to all station areas along transit corridors. While at a corridor-wide level the targets are appropriate and can help achieve transit-supportive growth, the updated Growth Plan policies seem to assume that all station areas will achieve these density targets by 2041. In reality, some transit station areas include stable communities that are unlikely to see higher density redevelopment and will not be able to achieve the Growth Plan targets. This generalized approach to density does not seem to recognize the distinct characteristics of each station area, and does not acknowledge that densities will vary from station to station depending on the local context" (De Franco). If increased density in many of these areas is to work, there must be an increased commitment to funding by the provincial and federal government.

During the period of time when the province was accepting commentary on the proposed Growth Plan, many GTA municipalities raised their concerns about meeting the proposed growth targets. A Peel Region report adopted by Council on October 13, 2016 highlights many of these concerns. They claim that the proposed density and intensification targets are unrealistic in relation to the forecasted growth of the Peel Region. Excluding potential employment lands, approximately 85 per cent of Peel's current designated growth area is estimated to be already built, or planned with approved secondary plans at densities of approximately 69 people and jobs per hectare. Therefore, under the proposed Growth Plan, the new targets would have to be realized within the remaining 15 per cent of unplanned lands. These communities would result in densities of approximately 140 residents and jobs per hectare located in the periphery of the Peel Region that lacks adequate transit and other necessary infrastructure (OHBA 7). Similarly, York Region claims that the proposed density and intensification targets are unattainable given the region's forecasted population. York claims that the identification of Major Transit Station Areas and associated density targets are context dependent and as such, should be determined by the municipality (OHBA 7). The County of Dufferin has stated "that applying the same intensification target to all municipalities is not reflective of the character and challenges facing each municipality, and greater flexibility should be considered" (OHBA 17). They go on to say, "consideration should be given to establishing a lower overall intensification target for municipalities within the outer ring, without a UGC, while maintaining their ability to seek alternative minimum intensification targets" (OHBA 17).

Other municipalities go on to comment about the inadequacy of planning by numbers. The City of Vaughan claimed that it cannot support the approval of the Growth Plan among other land use documents at their October 19, 2016 council meeting. Some reasons for this include, the implications of the increased density and intensification targets when combined, the failure to include clear transition policies, and the failure to include a review process for the evaluation of proposals for amendments to the Greenbelt's boundaries or proposals for permission to include additional compatible uses within the Greenbelt (City of Vaughan 2). And as a final example, the City of Pickering states, "the Province's new plan for growth does not give recognition to the dynamic and diverse character of the GTA, but treats it as a Toronto-centric 'one model fits all'. It is evident that the Province is 
not planning for 'complete communities', but rather planning by numbers, with little or no regard to aspects such as urban structure, community integrity, built form character, place-making, local housing affordability and choice, availability of transit and infrastructure, and financial capacity" (Rose). 


\subsection{RECOMMENDATIONS}

The following recommendations have been compiled into a comprehensive list based on the analysis in Section 4.

1. It is recommended that the province and municipalities immediately commence an inventory of the short-term land supply in relation to projected demand and supply and continue to monitor this as per requirements of the Provincial Policy Statement.

2. It is recommended that province and municipalities engage in conversation regarding funding tools to ensure an adequate amount of serviced land is provided to support demand and supply concerns and that policy tools to encourage or expedite the approval process of new projects is discussed.

3. It is recommended that adequate funding tools are determined specifically for Urban Growth Centres in order for higher density and intensification to be feasible in municipalities outside of Toronto.

4. It is recommended that the new Growth Plan support and respect the regional and municipal official plans and forecasting, and that the Growth Plan reflect the diversity of municipalities within the GGH.

5. It is recommended that the province update the built boundary to 2016 conditions and leave density and intensification targets as is (in the 2006 Growth Plan) with an option for municipalities to increase them if they see fit. Further, OHBA recommends (and is supported in this report) that the province recognize and differ between municipalities that (18):

- Are built or nearly built out

- Have existing or planned/funded higher order transit lines

- Have an Urban Growth Centre (UGC)/ Do not have an UGC

- $\quad$ Outer Ring vs Inner Ring

- Water/ Wastewater Infrastructure Capacity

4. It is recommended, in support of OHBA's recommendation (OHBA, 5), that in addition to the already provincially proposed exclusions, that the greenfield density be made a more predictable net community target by, at a minimum, excluding storm-water management infrastructure, arterial roads, cemeteries and employment lands for the proposed density calculation.

5. It is recommended that the new Greenbelt is determined through a scientific methodology that complements and supports the Growth Plan in order to mitigate the incentive for people to leap frog the Greenbelt and move further away from the GTHA. 


\subsection{NEXT STEPS}

The purpose of this MRP is to identify some of the economic issues that are being neglected by the Province and key decision makers in the process of the ten year review. As we look at land use regulation and the magnitude of the policy in Ontario we must be making informed and responsible decisions. As Professor Amborski states, "denying or ignoring these economic impacts is not the appropriate policy response. Rather, it is necessary to understand the impacts and consider them when formulating land use policy regulations, and making policy decisions that affect the affordability and pricing of houses" (Amborski 11). That being said, it is now up to the province to compile and study the suggestion and comments from economists, planners, and other industry experts that consider the economic environment of the GGH and incorporate those changes in the proposed Growth Plan.

The public input period closed on November 1, 2016 following the release of proposed changes to the Growth Plan for Greater Golden Horseshoe on May 10, 2016. Expectations for the release of the updated plans were for early 2017. There has been a delay in the release of the amended Growth Plan. This is due to the number of comments the province received encouraging a more detailed and scientific analysis of proposed amendments. The new Growth Plan will be released some time this year, but the issue now is that there will be no opportunity for further consultation. It can be assumed that given the delay of the release, substantial changes are being considered. As a final recommendation, there should be opportunity for further comments from interested parties. 


\subsection{WORKS CITED}

Advisory Committee on the Coordinated Review. (2015). "Planning for Health, Prosperity, and Growth in the Greater Golden Horseshoe: 2015-20141." Queen's Printer for Ontario, 2015. Retrieved from http:// www.mah.gov.on.ca/AssetFactory.aspx?did=11110

Allen, Rian and Pillippa Campsie. (2013). "Implementing the Growth Plan for the Greater Golden Horseshoe." Neptis Foundation, Toronto. Retrieved from http://www.neptis.org/sites/default/files/growth_plan_2013/ theneptisgrowthplanreport_final.pdf

Altus Group. (2017). "GTA Flash Report 2017." Altus Group Limited. Retrieved from http://emails.realnet.ca/ web_files/342/Campaign_Events\%20Images/2017-Event-Images/

DataSolutions_GTA_2017FlashReport_Online.pdf

Altus Group. (2017). "State of the Market Overview \& Outlook for 2017." Altus Group Limited. Toronto.

Amborski, David. (2016). "Affordability Housing and Land Supply Issues in the Greater Toronto Area (GTA)." Centre for Urban Research and Land Development, Ryerson University, Toronto. Retrieved from http:// www.ryerson.ca/content/dam/cur/pdfs/policycommentaries/CUR\%20Policy\%20Report_Affordable \%20Housing\%20and\%20Land\%20Supply\%20lssues\%20in\%20the\%20GTA_2016.11.04.pdf

Amborski, David, and Frank Clayton. (2016). "The Need to Make Housing Affordability a Primary Goal in Regional Planning for the Greater Golden Horseshoe." Centre for Urban Research and Land Development, Ryerson University, Toronto. Retrieved from http://www.ryerson.ca/content/dam/cur/pdfs/policycommentaries/ CUR\%20Policy\%20Report\%20_\%20Response\%20to\%20Proposed\%20Growth\%20Plan_2016.pdf

Canada Housing and Mortgage Corporation (CMHC). (2016). "Housing Market Outlook: Greater Toronto Area."

Canadian Housing and Mortgage Corporation (CMHC). (2017). "Housing Market Insight: Greater Toronto Area."

Canadian Real Estate Association. (2016). "Quarterly Forecasts.” The Canadian Real Estate Association, Ottawa. Retrieved from: http://www.crea.ca/housing-market-stats/quarterly-forecasts/

City of Vaughan. (2016). "Extract from Council Meeting Minutes of October 19, 2016." Item 18, Reports No. 34 of the Committee of the Whole. Retrieved from https://www.vaughan.ca/council/minutes_agendas/ Agendaltems/CW1005_16_18.pdf

Clayton, Frank. (2015). "Why There is a Shortage of New Ground-Related Housing in the GTA." Centre for Urban Research and Land Development, Ryerson University, Toronto. Retrieved from http://www.ryerson.ca/ content/dam/cur/images/CUR_PC\%234_Shortage_New_Ground-Related_Housing_June1\%2C \%202015.pdf

Clayton, Frank. (2016). "Will GTA Homebuyers Really Give Up Ground-Related Homes for Apartments?" Centre for Urban Research and Land Development, Ryerson University, Toronto. Retrieved from http:// www.ryerson.ca/content/dam/cur/pdfs/Projects/CUR\%20Report_Will\%20GTA\%20homebuyers\%20give \%20up\%20ground-related\%20houses\%20\%20for\%20apartments.pdf 
Clinkard, John. (2017). "Economic Commentary: Greater Golden Horseshoe New Housing Market Trends Q4 2016." Centre for Urban Research and Land Development, Ryerson University, Toronto. Retrieved from http://www.ryerson.ca/cur/publications/EconomicCommentaries/housingstarts_Q4/

Dawkins, Casey J. and Arthur C. Nelson. (2001). "Urban Containment Policies and Housing Prices: An International Comparison with Implications for Future Research." City Planning Program, College of Architecture, Georgia Institute of Technology, USA. Retrieved from https://www.academia.edu/ 26258144/Urban_containment_policies_and_housing_prices_an_international_comparison _with_ implications_for_future_research

De Franco, Antonio. (2016). "Leveraging Transit Infrastructure to Support Growth." Urban Strategies Inc. Toronto. Retrieved from http://www.urbanstrategies.com/blog/leveraging-transit-infrastructure-supportgrowth/

Knaap, Gerrit. (2003). "Land Supply and Infrastructure Capacity Monitoring for Smart Urban Growth." National Centre for Smart Growth, Maryland. Retrieved from https://www.academia.edu/4531165/ Land_Supply_and_Infrastructure_Capacity_Monitoring_for_Smart_Urban_Growth

Lee, Chang-Moo. (1999). "An Intertemporal Efficiency Test of a Greenbelt: Assessing the Economic Impacts of Seoul's Greenbelt." Journal of Planning Education and Research. Association of Collegiate Schools of Planning. Retrieved from http://journals1.scholarsportal.info.ezproxy.lib.ryerson.ca/pdf/0739456x/ v19i0001/41_aietoateiosg.xml

Malone Given Parsons Ltd. (2016). "Questions on the Proposed Growth Plan and Greenbelt Plan." Presented at BILD Past Presidents Dinner, Toronto.

Ministry of Municipal Affairs and Housing. (2014). "Provincial Policy Statement, 2014." Province of Ontario. Retrieved from http://www.mah.gov.on.ca/AssetFactory.aspx?did=10463

Ministry of Municipal Affairs and Housing. (2016). "Proposed Growth Plan for the Greater Golden Horseshoe." Province of Ontario. Retrieved from https://www. placestogrow.ca/content/ggh/Proposed\%20Growth \%20Plan\%20for\%20the\%20Greater\%20Golden\%20Horseshoe\%202016_2.pdf

Myers, Ben. (2017). "The Market Manuscript." Fortress Real Developments Inc.

Neptis Foundation. (2016). "No Shortage of Land for Homes in the Greater Toronto and Hamilton Area." Neptis Foundation, Toronto. Retrieved from http://www.neptis.org/publications/no-shortage-land-homesgreater-toronto-and-hamilton-area

New Zealand Productivity Commission.(2012). "Housing Affordability Inquiry." Retrieved from http:// productivity.govt.nz/sites/default/files/Final\%20Housing\%20Affordability\%20Report_0_0.pdf

New Zealand Productivity Commission. (2016). "Better Urban Planning - Draft Report." Retrieved from http:// www.productivity.govt.nz/sites/default/files/better-urban-planning-draft-report_1.pdf

Ontario Home Builders' Association (OHBA). (2016). "Co-ordinated Review Proposed Growth Plan for the Greater Golden Horseshoe." EBR: 012-7194. Retrieved from http://ohba.ca/system/documents/documents/ 417/original/OHBA_-_Coordinated_Review_-_Growth_Plan_Submission_-_Final_-_2016.pdf?1477946048 
Ontario Ministry of Finance. (2016). "Ontario Population Projections Update, 2015-2041: Spring 2016 (Based on 2011 Census)." Queens Printer for Ontario: 2016. Retrieved from http://www.fin.gov.on.ca/en/economy/ demographics/projections/projections2015-2041.pdf

Paul C. Cheshire, Max Nathan, and Henry G. Overman. (2014). "Urban Economics and Urban Policy: Challenging Conventional Policy Wisdom." Edward Elgar Publishing Limited: United Kingdom, USA.

RBC Economics. (2017). "Canadian Housing Health Check." Royal Bank of Canada. Retrieved from http:// www.rbc.com/economics/economic-reports/canadian-housing-forecast.html

Rose, Catherine. (2016). “2015 Coordinated Review of Ontario's Land Use Plans. City of Pickering Comments on the Proposed Changes to the Growth Plan for Greater Golden Horseshoe, the Greenbelt Plan, and the Oak Ridges Conservation Plan." Report Number PLN 15-16. City of Pickering. Retrieved from https:// corporate.pickering.ca/weblink8/1/doc/155549/Page1.aspx

Seoul's Greenbelt." Journal of Planning Education and Research. Association of Collegiate Schools of Planning. Retrieved from http://journals1.scholarsportal.info.ezproxy.lib.ryerson.ca/pdf/0739456x/ v19i0001/41_aietoateiosg.xml

TD Economics. (2015). "GTA Housing Boom Masks Growing Structural Challenges." TD Economics, Toronto. Retrieved from https://www.td.com/document/PDF/economics/special/GTA_Housing.pdf

TD Economics. (2016). "Regional Housing Report." TD Economics, Toronto. Retrieved from https:// www.td.com/document/PDF/economics/special/RegionalHousing_Aug2016.pdf

The White House. (2016). "Housing Development Toolkit." Washington D.C. Retrieved from https:// www.whitehouse.gov/sites/whitehouse.gov/files/images/Housing_Development_Toolkit\%20f.2.pdf

White, Richard. (2007). "The Growth Plan for the Greater Golden Horseshoe in Historical Perspective." The Neptis Foundation, Toronto. Retrieved from http://www.neptis.org/sites/default/files/ historical_commentary/historicalcomm_web_200711291.pdf 